\title{
Sistem Pakar Dengan Metode Certainty Factor Dalam Penentuan Gaya Belajar Anak Usia Remaja
}

\author{
Wita Yulianti ${ }^{1}$, Liza Trisnawati ${ }^{2}$, Theresia Manullang ${ }^{3}$ \\ 1,2,3 Program Studi Teknik Informatika Fakultas Teknik Universitas Abdurrab) \\ (Jl. Riau Ujung No. 73 Payung Sekaki, Pekanbaru, Riau, telp. 08116911056) \\ e-mail: ${ }^{1}$ wita.yulianti@univrab.ac.id, ${ }^{2}$ liza.trisnawati@univrab.ac.id, \\ 3ismailt.informatika@ymail.com
}

\begin{abstract}
Abstrak
Masa remaja merupakan suatu rentang kehidupan individu. Dalam siklus perkembangan individu, masa remaja merupakan kehidupan yang sangat penting dan masa peralihan yang perlu diarahkan pada perkembangan menuju dewasa. Lingkungan keluarga yang sehat dan lingkungan yang kondisif untuk tumbuh kembang remaja yang positif dapat mempengaruhi kematangan fisik dan psikis remaja, maka dari itu perlu tindakan yang dapat membantu remaja menemukan tujuan dalam kehidupan. Ilmu psikologi merupakan bidang ilmu yang dapat mengetahui perilaku manusia dan mempelajari proses mental manusia. Ilmu psikologi dalam mempelajari sisi psikologi suatu objek masih menggunakan metode konvensional. Dalam hal mengamati gaya belajar remaja, perpaduan antara ilmu psikologi dan teknologi memungkinkan untuk dilakukan, yaitu dengan membuat sebuah sistem berbasis teknologi (sistem pakar) berdasarkan pengetahuan pakar. Sistem pakar ini dapat memberi pengetahuan dalam penentuan gaya belajar remja dengan menerapkan metode dari sistem pakar yaitu certainty factor. Certainty factor dapat memberikan nilai kepercayaan dari nilai ketipastian dengan menghitung nilai certainty factor dan hasil nilai kombinasi certainty factor sesuai ketentuan dari metode. Hasil perhitungan certainty factor berbentuk nilai (angka) di setiap gaya belajar, di mana hasil tertinggi menjadi penetuan gaya belajar. Hasil dari penelitian ini, para pakar (psikolog) dapat menentukan gaya belajar dengan lebih cepat dan pendidik atau pengajar dapat terbantu dalam mengetahui modalitas atau gaya belajar remaja serta dapat memberikan solusi bagi remaja arah bakat atau karir sesuai gaya belajar diperoleh. Bagi akademisi atau praktisi dibidang teknologi, akan didapat hasil bahwa metode Certainty Factor yang dapat menentukan gaya belajar dengan melihat dari perolehan nilai dari setiap gaya belajar.
\end{abstract}

Kata kunci: Ilmu Psikologi, Remaja, Gaya Belajar, Sistem Pakar, Certainty Factor

\begin{abstract}
Abstrack
Adolescence is an individual's life span. In the individual development cycle, adolescence is a very important life and a transitional period that needs to be directed at development towards adulthood. A healthy family environment and an environment that is conducive to adolescent growth and development that can positively affect adolescent physical and psychological maturity, therefore need actions that can help teens find goals in life. Psychology is a field of science that can know human behavior and study human mental processes. Psychology in studying the psychology of an object still uses conventional methods. In terms of observing adolescent learning styles, a combination of psychology and technology makes it possible to do, namely by making a technology-based system (expert system) based on expert knowledge. This study will discuss how to create an expert system with the certainty factor method. From the results of this study, experts in this case psychologists and educators or
\end{abstract}


instructors can be helped in seeing the modalities or learning styles of adolescents. While for academics or practitioners in the field of technology, results will be obtained that the Certainty Factor method can determine learning styles.

Keywords: Psychology, adolescence, Learning Style, Expert Systems, Certainty Factor

\section{Pendahuluan}

Masa remaja merupakan suatu rentang kehidupan individu. Dalam siklus perkembangan individu, masa remaja merupakan kehidupan yang sangat penting dan masa peralihan yang perlu diarahkan pada perkembangan menuju dewasa. Lingkungan keluarga yang sehat dan lingkungan yang kondisif untuk tumbuh kembang remaja yang positif dapat mempengaruhi kematangan fisik dan psikis remaja[1].

Ilmu psikologi merupakan bidang ilmu yang dapat mengetahui perilaku manusia dan mempelajari proses mental manusia. Melihat hal tersebut bahwa ilmu psikologi merupakan sebuah ilmu pengetahuan yang kemungkinan melibatkan pemanfaatan teknologi di dalamnya. Pada prakteknya, Ilmu psikologi dalam mempelajari sisi psikologi suatu objek masih menggunakan metode konvensional. Objek yang dimaksud adalah manusia dengan sikap dan tingkah lakunya [2]. Gaya belajar anak atau modalitas belajar adalah cara informasi masuk ke dalam otak melalui indra yang dimiliki. Saat informasi akan ditangkap oleh indra, maka informasi yang disampaikan (modalitas) berpengaruh pada kecepatan otak menangkap informasi dan kekuatan otak menyimpan informasi dalam ingatan atau memori.informasi akan lebih cepat diterima oleh otak apabila sesuai dengan gaya belajar seseorang (penerima informasi). Umumnya, gaya belajar seseorang berasal dari variabel kepribadian, termasuka susunan kognitif dan psikologis latar belakang sosio cultural, dan pengalaman pendidikan[3].

Dalam hal mengamati gaya belajar remaja, perpaduan antara ilmu psikologi dan teknologi memungkinkan untuk dilakukan, yaitu dengan membuat sebuah sistem berbasis teknologi berdasarkan pengetahuan pakar (sistem pakar) [4]. Sistem pakar diturunkan dari istilah Knowledge-Based Expert Sistem. Istilah ini muncul, untuk memecahkan masalah. Sistem pakar menggunakan pengetahuan berdasarkan pakar yang dimasukkan ke dalam komputer [5]. Sistem pakar dibuat dengan tujuan untuk dapat menyelesaikan masalah yang cukup rumit dan hanya bisa diselesaikan oleh para ahli. Pembuatan sistem pakar bukan untuk menggantikan para ahli itu sendiri melainkan dapat digunakan sebagai asisten yang sangat berpengalaman [6]. Pada penelitian ini membahas bagaimana membuat sebuah sistem pakar bermetodekan Certainty factor. Certainty factor (CF) merupakan nilai parameter klinis yang diberikan MYCIN untuk menunjukkan besarnya kepercayaan. Certainty factor didefenisikan sebagai persamaan berikut

$C F(H, E)=M B(H, E)-M D(H, E)$

Bentuk dasar rumus certainty factor, adalah sebuah aturan jika $\mathrm{E}$ maka $\mathrm{H}$ seperti ditunjukkan oleh persamaan berikut:

$$
C F(H, e)=C F(E, e) * C F(H, E)[7]
$$

Metode certainty factor hanya bisa mengolah dua bobot dalam sekali perhitungan. Untuk bobot yang lebih dari dua, untuk melakukan perhitungan tidak terjadi masalah apabila bobot yang dihitung teracak, artinya tidak ada aturan untuk mengkombinasikan bobotnya, karena untuk kombinasi seperti apapun hasilnya akan tetap sama. Hasil dari penelitian ini, psikolog dan pendidik atau pengajar dapat terbantu dalam melihat modalitas atau gaya belajar remaja. Sedangkan bagi akademisi atau praktisi dibidang teknologi, akan didapat hasil bahwa metode Certainty Factor dapat menentukan gaya belajar.

Adapun tujuan penerapan metode certainty factor dalam menentukan gaya belajar usia remaja. Pertama, untuk membuat sebuah sistem pakar dengan menerapkan metode Certainty factor berdasarkan kajian dari pakar dan pembobotan yang telah dilakukan. Kedua, membantu 
psikolog dalam menganalisis gaya belajar remaja yang berbasis teknologi informasi. Ketiga, pengguna sistem pakar dapat mengetahui gaya belajar dengan cepat.

Setelah tujuan tercapai, hasil dari penelitian ini memiliki manfaat: Certainty Factor dapat memberikan nilai keyakinan dari setiap gaya belajar dalam menentukan gaya belajar, sistem pakar ini dapat memudahkan pekerjaan psikolog dalam menganalisis penentuaan gaya belajar anak usia remaja, memberikan solusi bagi remaja dalam menentukan bakat atau karir sesuai gaya belajar.

Dalam penelitian Rizal Rachman dan Amirul Mukminin, tahun 2018 dengan judul "Penerapan Metode Certainty Factor pada Sistem Pakar Penentuan Minat dan Bakat Siswa SD", dengan hasil kesimpulan bahwa metode certainty factor dapat menentukan minat dan bakat berdasarkan ciri-ciri. Sistem pakar ini dapat menjadi alternatif membantu para guru, orang tua siswa atau siswa sendiri dalam menentukan minat dan bakat. Informasi yang diberikan tentang kecerdasan, minat dan bakat baik itu jenis, ciri-ciri ataupun stimulasi minat dan bakat dengan cara yang mudah [8]. Penelitian atas nama Muhammad Ibrohim dan Novi Purwanty, tahun 2017 dengan judul "Rancang Bangun Aplikasi Identifikasi Gaya Belajar Siswa Dengan Metode Forward Chaining", dengan hasil kesimpulan bahwa sistem pakar dapat memudahkan dalam melakukan identifikasi gaya belajar siswa dengan mengumpulkan ciri-ciri gaya belajar sesuai aturan rule yang ada dan metode forward chaining dapat diketahui cara mengajar dan cara belajar yang sesuai dengan gaya belajar yang dimiliki dari masing-masing siswa[9]

Penelitian atas nama Aryu Hanifah Aji, M. Tanzil Furqon, dan Agus Wahyu Widodo, tahun 2018 dengan judul Sistem Pakar Diagnosa Penyakit Ibu Hamil Menggunakan Metode Certainty Factor, dengan hasil kesimpulan bahwa sistem pakar ini dapat mendiagnosa sebuah penyakit ibu hamil dengan memberikan informasi berupa presentase maksimal, definisi penyakit, pencegahan dan rujukan bagi ibu hamil. Serta sebagai alternatif bagi ibu hamil dalam mengenali tanda bahaya melalui gejala-gejala yang dirasakan, dan memperoleh informasi dalam membantu ibu hamil dalam menunjukkan tempat rujukan yang tepat sehingga dapat ditangani oleh paramedis dengan tepat pula [10]. Penelitian sebelumnya dapat memberikan inpirasi bagi penulis berikutnya. Setiap penelitian pasti ada kelebihan dan kelemahan dari hasil penelitian tersebut (berupa produk atau analisis). Dari ketiga penelitian ini dapat memberikan kontribusi dan dapat melakukan riset kembali. Dari penelitian pertama, dapat dilakukan menggunakan metode certainty factor untuk melihat tingkat IQ siswa SD sebelum melihat minat bakat siswa tersebut. Penelitian kedua, penentuan gaya belajar siswa dengan menerapkan metode sistem pakar selain dari forward chaining. Penelitian ketiga, mengenai diagnosa penyakit ibu hamil tapi ada kekurangannya untuk ruang lingkupnya. Penyakit ibu hamil berbagai macam selama seorang ibu hamil bagi penelitian ketiga memungkinkan dapat dikecilkan ruang lingkupnya atau ditambahkan diagnosa tingkat emosional bagi ibu hamil.

\section{Metode Penelitian}

Dalam menyelesaikan tahap penelitian, peneliti melakukan penelitian yang terdiri dari analisis masalah, pengumpulan data, analisis kebutuhan, analisis data (perhitungan metode), perancangan dan pembuatan sistem pakar, dan implementasi. Gambar tahapan atau metode penelitian dapat dilihat pada gambar 1di bawah.

Berikut penjelasaan gambar 1 kerangka kerja penelitian yang merupakan proses tahapan melakukan penelitian:

1. Analisis masalah merupakan tahapan melakukan menganalisa masalah yang terjadi pada beberapa psikolog untuk menyelesaikan beberapa kasus dalam menemukan gaya belajar seorang remaja dengan proses ketentuan yang berlaku secara konvensional di dunia psikologi. Masalah-masalah yang terjadi akan diidentifikasi dan ditemukan solusi

eISSN: 2477-3255, pISSN: 2086-4884 https://doi.org/10.31849/digitalzone.v10i2. 2781 
permasalahannya. Hipotesa dari permasalahannya, penulis memberikan solusi untuk membantu permasalahannya dengan cara merancang dan membuat sebuah sistem pakar certainty factor dalam menentukan gaya belajar seorang remaja.

2. Dengan ditemukan solusi untuk permasalahan yang terjadi, maka penulis melakukan pengumpulan data dengan dua tahap yaitu, studi pustaka dan studi lapangan. Studi pustaka merupakan pengumpulan data melalui beberapa referensi dari buku, jurnal, diktat atau yang lainnya yang sesuai topik penelitian. Studi lapangan, tahapan pengumpulan data dari beberapa pakar mengenai gaya belajar dan beberapa remaja yang menjadi objek penelitian.

3. Selanjutnya penulis membuat analisis kebutuhan yang merupakan beberapa data untuk kebutuhan dalam pengembangan penelitian sebuah sistem pakar berupa basis pengetahuan mengenai gaya belajar yang menjadi dasar untuk perhitungan metode sistem pakar certainty factor dan kebutuhan sistem pakar berupa hardware dan software.

4. Kebutuhan dalam perhitungan manual certainty factor dalam mengolah data berupa basis pengetahuan mengenai dari gaya belajar.

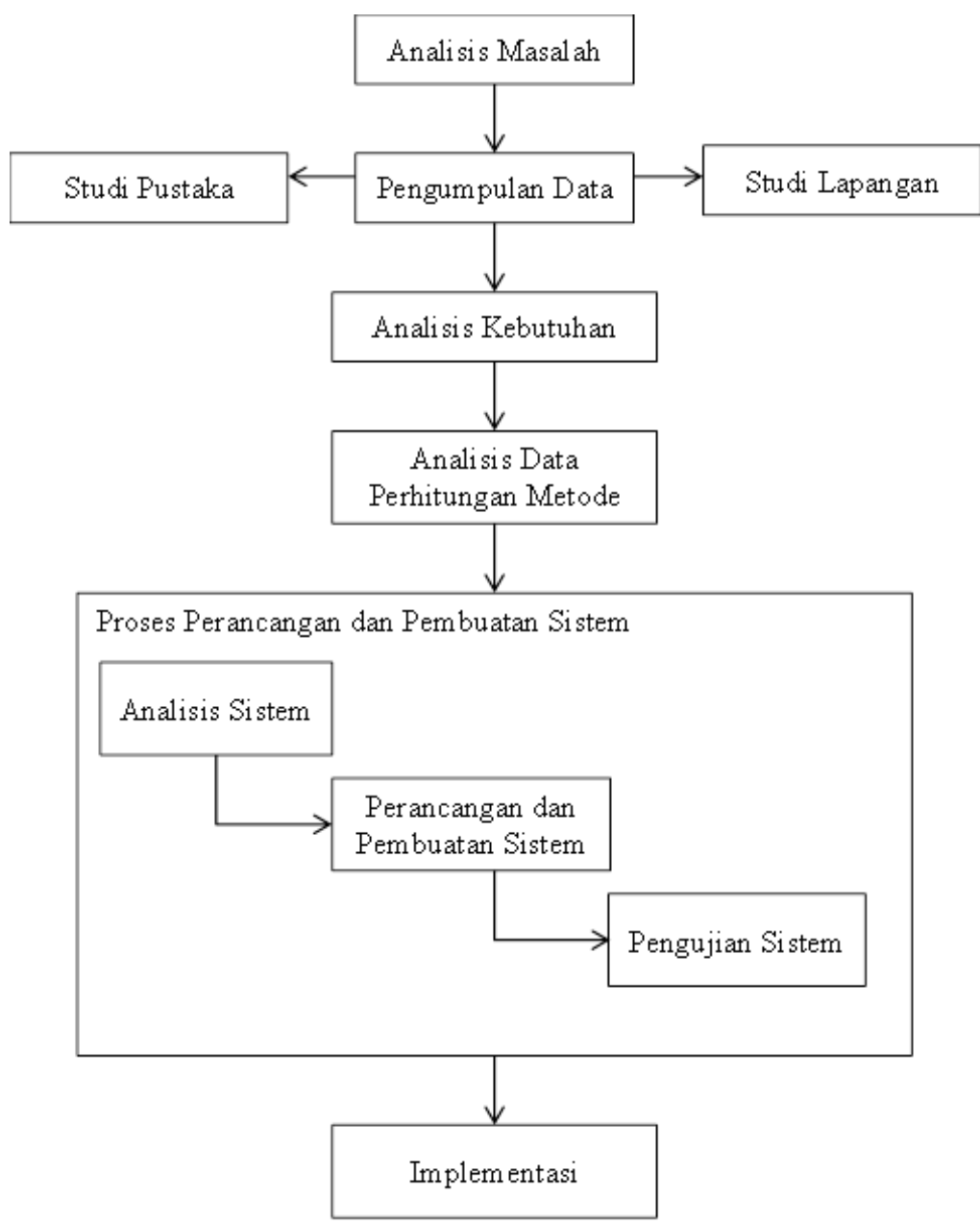

Gambar 1 Kerangka Penelitian

Berikut basis pengetahuan yang merupakan kumpulan-kumpulan fakta. Beberapa struktur basis pengetahuan adalah sebagai berikut: 
Tabel 1 Basis Pengetahuan Gaya Belajar

\begin{tabular}{|c|l|}
\hline Kode & \multicolumn{1}{|c|}{ Gaya Belajar } \\
\hline V & Visual \\
\hline A & Audio \\
\hline K & Kinestetik \\
\hline
\end{tabular}

Tabel 2 Basis Pengetahuan Ciri-Ciri Gaya Belajar

\begin{tabular}{|c|l|}
\hline Kode & \multicolumn{1}{|c|}{ Ciri-Ciri Gaya Belajar } \\
\hline v1 & Teratur dan rapi \\
\hline v2 & Pengatur jangka panjang dan perencana yang baik \\
\hline v3 & Berbicara secara cepat \\
\hline v4 & Mengetahui yang harus dikatakan, tetapi tidak terpikir kata yang sesuai \\
\hline v5 & Mengeja dengan baik dan dapat melihat kata-kata yang ada dipikiran \\
\hline v6 & Lebih mengingat yang dilihat daripada yang didengar \\
\hline v7 & Dapat menghafal dengan asosiasi visual \\
\hline v8 & $\begin{array}{l}\text { Sulit mengingat perintah secara lisan kecuali dituliskan dan sering meminta } \\
\text { bantuan mengulang ucapannya }\end{array}$ \\
\hline v9 & Lebih suka membaca \\
\hline v10 & Mencoret-coret saat menelepon atau menghadiri rapat \\
\hline v11 & Lebih menyukai seni \\
\hline v12 & Suka melakukan demontrasi \\
\hline a1 & Dapat terganggu dengan keributan \\
\hline a2 & Dapat menirukan nada, perubahan, dan warna suara dan mengulangnya kembali \\
\hline a3 & Belajar secara mendengar dan mengingat apa yang didiskusikan \\
\hline a4 & Berbicara dengan diri sendiri saat beraktivitas \\
\hline a5 & Melafalkan kata-kata saat membaca dengan menggerakkan bibir \\
\hline a6 & Lebih senang mendengarkan dan membacanya keras-keras \\
\hline a7 & Lebih baik mengeja keras-keras daripada menuliskannya \\
\hline a8 & Lebih menyukai musik daripada seni \\
\hline a9 & Lebih baik bercerita daripada menulis \\
\hline a10 & Berbicara secara berirama \\
\hline a11 & Pembicara yang fasih \\
\hline a12 & Lebih banyak bicara, senang berdiskusi, dan menjelaskan dengan panjang lebar \\
\hline k1 & Lebih sering menggunakan isyarat tubuh \\
\hline k2 & Tidak bisa duduk tenang dengan waktu yang lama \\
\hline k3 & Saat mendengarkan lebih sering mengetuk-ngetuk pena, jari, atau kaki \\
\hline k4 & Lebih banyak bergerak secara fisik \\
\hline k5 & Menunjuk dengan jari saat membaca \\
\hline k6 & Berbicara dengan lambat \\
\hline k7 & Menghafal dengan berjalan dan melihat \\
\hline k8 & Lebih banyak kegiatan fisik dan meluangkan waktu untuk berolahraga \\
\hline k9 & Untuk mendapatkan perhatian dengan cara menyentuh orang \\
\hline k10 & Berdiri dekat-dekat saat berbicara dengan seseorang \\
\hline k11 & Membuat keputusan berdasarkan perasaan \\
\hline k12 & Belajar melalui menipulasi dan praktik \\
\hline & \\
\hline
\end{tabular}


Tabel 3 Basis Pengetahuan Rule

\begin{tabular}{|c|c|}
\hline Kode & Rule \\
\hline $\mathrm{r} 1$ & $\begin{array}{l}\text { IF teratur dan rapi } \\
\text { AND pengatur jangka panjang dan perencana yang baik } \\
\text { AND berbicara secara cepat } \\
\text { AND mengetahui yang harus dikatakan, tetapi tidak terpikir kata yang sesuai } \\
\text { AND mengeja dengan baik dan dapat melihat kata-kata yang ada dipikiran } \\
\text { AND lebih mengingat yang dilihat daripada yang didengar } \\
\text { AND dapat menghafal dengan asosiasi visual } \\
\text { AND sulit mengingat perintah secara lisan kecuali dituliskan dan sering } \\
\text { meminta bantuan mengulang ucapannya } \\
\text { AND lebih suka membaca } \\
\text { AND mencoret-coret saat menelepon atau menghadiri rapat } \\
\text { AND lebih menyukai seni } \\
\text { AND suka melakukan demontrasi } \\
\text { THEN VISUAL }\end{array}$ \\
\hline $\mathrm{r} 2$ & $\begin{array}{l}\text { IF dapat terganggu dengan keributan } \\
\text { AND dapat menirukan nada, perubahan, dan warna suara dan mengulangnya } \\
\text { kembali } \\
\text { AND belajar secara mendengar dan mengingat apa yang didiskusikan } \\
\text { AND berbicara dengan diri sendiri saat beraktivitas } \\
\text { AND melafalkan kata-kata saat membaca dengan menggerakkan bibir } \\
\text { AND lebih senang mendengarkan dan membacanya keras-keras } \\
\text { AND lebih baik mengeja keras-keras daripada menuliskannya } \\
\text { AND lebih menyukai musik daripada seni } \\
\text { AND lebih baik bercerita daripada menulis } \\
\text { AND berbicara secara berirama } \\
\text { AND pembicara yang fasih } \\
\text { AND lebih banyak bicara, senang berdiskusi, dan menjelaskan dengan } \\
\text { panjang lebar } \\
\text { THEN AUDIO }\end{array}$ \\
\hline r3 & $\begin{array}{l}\text { IF lebih sering menggunakan isyarat tubuh } \\
\text { AND tidak bisa duduk tenang dengan waktu yang lama } \\
\text { AND saat mendengarkan lebih sering mengetuk-ngetuk pena, jari, atau kaki } \\
\text { AND lebih banyak bergerak secara fisik } \\
\text { AND menunjuk dengan jari saat membaca } \\
\text { AND berbicara dengan lambat } \\
\text { AND menghafal dengan berjalan dan melihat } \\
\text { AND lebih banyak kegiatan fisik dan meluangkan waktu untuk berolahraga } \\
\text { AND untuk mendapatkan perhatian dengan cara menyentuh orang } \\
\text { AND berdiri dekat-dekat saat berbicara dengan seseorang } \\
\text { AND membuat keputusan berdasarkan perasaan } \\
\text { AND belajar melalui menipulasi dan praktik } \\
\text { THEN KINESTETIK }\end{array}$ \\
\hline
\end{tabular}


Tabel 4 Kebutuhan Hardware dan Software

\begin{tabular}{|l|l|}
\hline Jenis Kebutuhan & \multicolumn{1}{c|}{ Uraian } \\
\hline \multirow{4}{*}{ Hardware } & Laptop atau Komputer Desktop \\
\cline { 2 - 2 } & Minimal RAM 2 GB \\
\cline { 2 - 2 } & Minimal Hardsik 500 GB \\
\hline \multirow{4}{*}{ Software } & Microsoft Windows7/8/10 \\
\cline { 2 - 2 } & Microaoft Visual Basic.Net \\
\cline { 2 - 2 } & Microsoft Office Accesss \\
\cline { 2 - 2 } & Microsoft Office 2007/2010/2013/2016 \\
\hline
\end{tabular}

5. Analisa Data

Dala tahap analisa data, di mana proses ini melakukan perhitungan metode certainty factor dalam menentukan gaya belajar. Proses dalam menentukan gaya belajar dimulai ketika mamasukkan ciri-ciri gaya belajar. Ciri-ciri yang diperoleh akan diproses melalui cara rule base untuk mengetahui kemungkinan gaya belajar berdasarkan pakar psikolog. Rule base atau bisa juga disebut dengan knowledge base merupakan representasi dari pakar atau psikolog dinyatakan dalam bentuk rule sebagai tempat menyimpan pengetahuan dan analisa dari psikolog. Penggunaan metode certainy factor dalam menentukan gaya belajar anak usia remaja dengan gejala-gejala yang dialami.

6. Perancangan dan Pembuatan Sistem

Perancangan dan pembuatan sistem merupakan proses pembuatan sistem pakar dalam menentukan gaya belajar remaja. Dalam tahap ini, ada beberapa tahapan atau proses dalam menghasilkan sebuah sistem pakar. Pertama, analisis sistem yang menjadi dasar dalam pembuatan sistem seperti, aliran sistem informasi (flowchart), context Diagram, DFD, dan ERD. Proses kedua, pembuatan sistem yang berbasis desktop. Langkah selanjutnya, tahap pengujian sistem untuk melakukan evaluasi pada sistem pakar gaya belajar dengan menguji proses kerja sistem dengan objek penelitian.

7. Implementasi

Tahap implementasi merupakan tahapan penerapan sistem pakar gaya belajar di tempat praktek psikolog ataupun di sekolah.

\section{Hasil dan Pembahasan}

\section{Analisis Data (Perhitungan Certainty Factor)}

Dari data yang telah diperoleh dari objek penelitian pada beberapa remaja. Data tersebut diolah dengan metode sistem pakar certainty factor. Data yang diperoleh diolah dengan basis pengetahuan untuk mencari nilai certainty factor dan certainty factor combine. Tabel 5 di bawah merupakan tabel hasil dari perhitungan certanty factor combine. Perhitungan akhir dari certainty factor combine adalah hasil penentuan gaya belajar dari seseorang anak remaja.

Tabel 5 Hasil

\begin{tabular}{|c|l|c|c|c|}
\hline No & \multicolumn{1}{|c|}{ Kasus } & Visual & Audio & Kinestetik \\
\hline 1 & Kasus I & $73,3 \%$ & $79,8 \%$ & $83,4 \%$ \\
\hline 2 & Kasus II & $72,6 \%$ & $77,4 \%$ & $76,7 \%$ \\
\hline 3 & Kasus III & $74,3 \%$ & $78,1 \%$ & $77,4 \%$ \\
\hline
\end{tabular}


Tabel 6, terdapat tiga sampel yang telah diperoleh hasil dengan perhitungan secara certainty factor dalam menentukan gaya belajar dari kuesioner yang telah diisi oleh anak berusia remaja. Berikut ini tabel merupakan kesimpulan gaya belajar dari tiga kasus yang menjadi sampel.

Tabel 6 Kesimpulan Gaya Belajar

\begin{tabular}{|c|l|c|c|}
\hline No & \multicolumn{1}{|c|}{ Kasus } & Gaya Belajar & Nilai \\
\hline 1 & Kasus I & Kinestetik & $83,4 \%$ \\
\hline 2 & Kasus II & Audio & $77,4 \%$ \\
\hline 3 & Kasus III & Audio & $78,1 \%$ \\
\hline
\end{tabular}

\section{Analisis Sistem}

Analisis sistem termasuk perancangan sistem pada program sistem pakar ini berupa aliran sistem dalam bentuk flowchart. Aliran sistem ini memperlihatkan perubahan dalam penentuan gaya belajar remaja dari sebelum memakai sistem pakar dan setelah memakai sistem pakar.

a. Flowchart Sistem Sedang Berjalan

Merupakan flowchart sistem saat sebelum menggunakan sistem pakar dalam menentukan gaya belajar remaja.

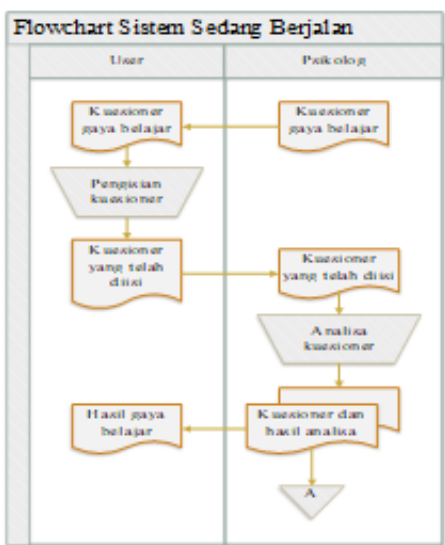

Gambar 2 Flowchart Sistem Sedang Berjalan

b. Flowchart Sistem Komputerisasi

Merupakan flowchart sistem komputerisasi setelah menggunakan sistem pakar dalam menentukan gaya belajar remaja

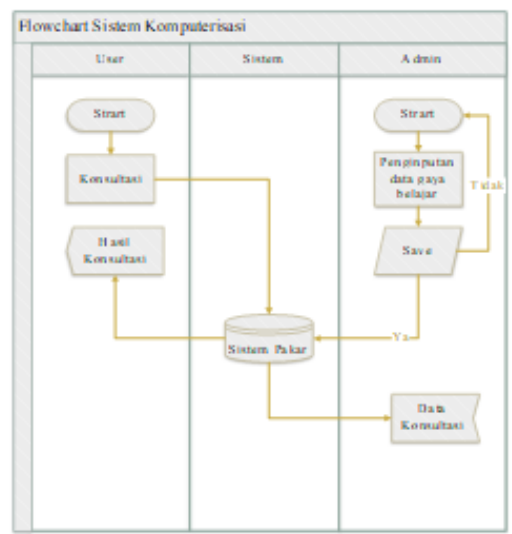

Gambar 3 Flowchart Sistem Komputerisasi 
c. Context Diagram Sistem

Context Diagram Sistem pada sistem pakar ini merupakan proses kegiatan sistem secara garis besar yang terhubung dengan beberapa pengguna.

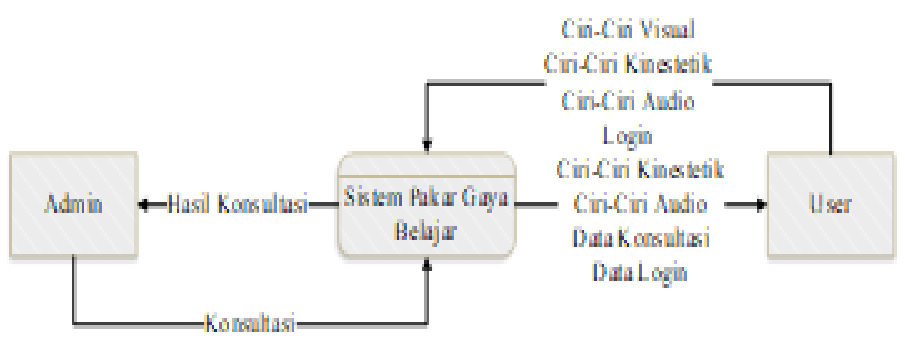

\section{Gambar 4 Context Diagram Sistem Pakar}

\section{Interface Sistem Pakar}

Berikut ini merupakan interface sistem pakar gaya belajar untuk remaja

a. Halaman Konsultasi Gaya Belajar

Merupakan halaman konsultasi gaya belajar yang digunakan admin atau pakar (psikolog) untuk menentukan gaya belajar remaja.

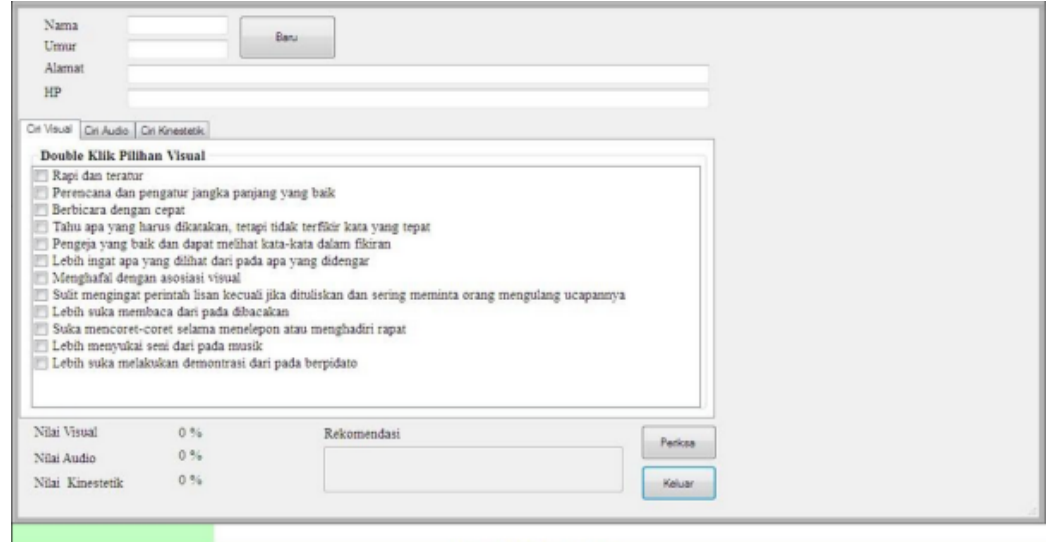

\section{Gambar 5 Halaman Konsultasi Gaya Belajar}

b. Halaman Hasil Konsultasi Gaya Belajar

Merupakan halaman hasil konsultasi gaya belajar setalah pasien berkonsultasi dengan psikolog menggunakan sistem pakar gaya belajar. 


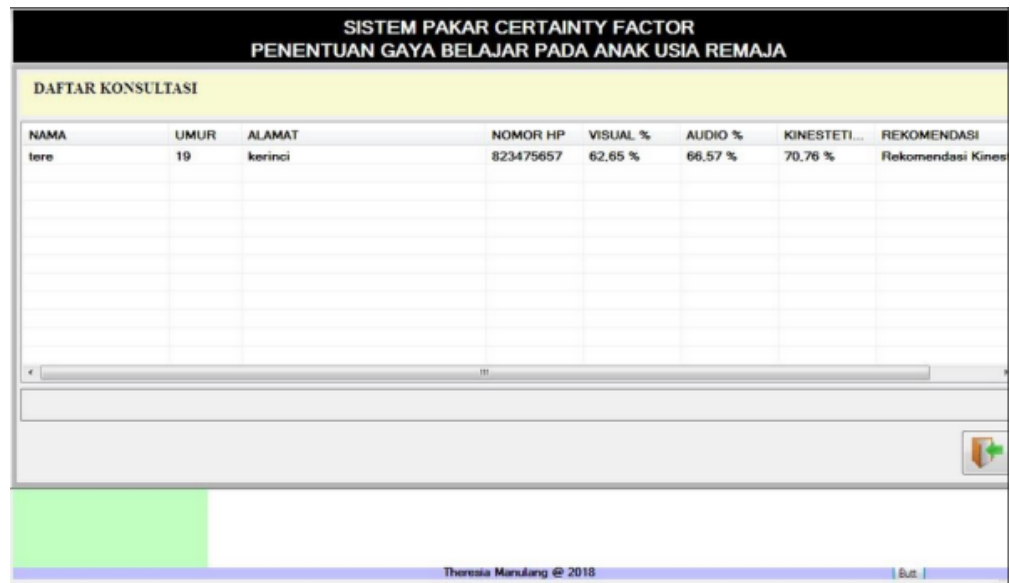

\section{Gambar 6 Halaman Hasil Konsultasi Gaya Belajar}

\section{Kesimpulan}

Dari hasil analisa dan pembahasan yang telah dibuat, maka didapatlah kesimpulan Sistem pakar dengan metode certainty factor menghasilkan nilai ketidakpastian menjadi hasil yang dapat memberikan penilaian bagi pengguna. Dalam perhitungan manual metode ini memberikan nilai akhir setiap gaya belajar dan hasil ini diperoleh dari perhitungan sesuai aturan metode dengan memberikan nilai pembobotan dari setiap ciri-ciri gaya belajar dan bobot jawaban dari hasil pernyataan yang diberikan kepada remaja yang telah ditentukan pakar dari beberapa pakar yang dipilih. Nilai diperoleh dari masing-masing gaya belajar setiap anak dengan perolehan nilai, untuk kasus 1, 2, dan 3 perolehan nilai visual $(73,3 \%),(72,6 \%),(74,3 \%)$, audio $(79,8 \%)$, $(77,4 \%),(78,1 \%)$, kinestetik $(83,4 \%),(76,7 \%),(77,4 \%)$. Hasil kesimpulan perolehan gaya belajar setiap anak remaja dengan metode certainty factor, untuk kasus 1 dengan gaya belajar kinestetik (83,4\%), kasus 2 dengan gaya belajar audio (77,4\%), untuk kasus 3 dengan gaya belajar audio $(78,1 \%)$. Sistem pakar gaya belajar usia remaja ini berbasiskan desktop yang digunakan pakar psikolog untuk berkonsultasi dengan pasiennya.

\section{Daftar Pustaka}

[1] Jannah, M. Remaja Dan Tugas-Tugas Perkembangannya Dalam Islam. Psikoislamedia: Jurnal Psikologi, 1(1), 243-256. 2017

[2] Arisandi, D., \& Saputra, A. Aplikasi Sistem Pakar Untuk Menentukan Gaya Belajar Anak Usia Sekolah Dasar. Teknologi Informasi Dan Komunikasi Digital Zone, 6(x), 12-17. 2015

[3] Chania, Y., Haviz, M., \& Sasmita, D. Hubungan Gaya Belajar Dengan Hasil Belajar Siswa Pada Pembelajaran Biologi Kelas X Sman 2 Sungai Tarab Kabupaten Tanah Datar. Sainstek: Jurnal Sains Dan Teknologi, 8(1), 77. 2019

[4] Arisandi, D. Pengujian Rule Pada Sistem Pakar Penanganan Cedera Olahraga Bola Basket. RABIT (Jurnal Teknologi Dan Sistem Informasi UNIVRAB), 1(2), 94-103.2016

[5] Yulianti, W. Aptitude Testing Berbasis Case-Based Reasoning Dalam Sistem Pakar Untuk Menentukan Minat Dan Bakat Siswa Sekolah Dasar. Jurnal Teknologi Dan Sistem Informasi UNIVRAB, 1(2), 104-118. 2016

[6] Rezza, R., Astuti, I. F., \& Cahyadi, D. Sistem Pakar Diagnosis Penyakit Kulit Pada Kucing Menggunakan Metode Certainty Factor. Prosiding Seminar Ilmu Komputer Dan Teknologi Informasi, 2(1), 263-269. 2017 
[7] Sihotang, H. TSistem Pakar Mendiagnosa Penyakit Kolesterol Pada Remaja Dengan Metode Certainty Factor (Cf) Berbasis Web. Jurnal Mantik Penusa, 15(1), 16-23. . 2014

[8] Rachman, R., \& Mukminin, A. Penerapan Metode Certainty Factor Pada Sistem Pakar Penentuan Minat dan Bakat Siswa SD. Khazanah Informatika: Jurnal Ilmu Komputer Dan Informatika, 4(2), 90.2019

[9] Ibrohim, M., Purwanty, N., Dunn, R., John, S., Bandler, R., Grinder, J., \& Grinder, M. Rancang Bangun Aplikasi Identifikasi Gaya Belajar Siswa Dengan Metode Forward Chaining ( Studi Kasus : Sekolah Dasar Negeri Sumampir ). 4, 19-28. 2017

[10] Aji, A. H., Furqon, M. T., \& Widodo, A. W. Sistem Pakar Diagnosa Penyakit Ibu Hamil Menggunakan Metode Certainty Factor ( $\mathrm{CF}$ ). Jurnal Pengembangan Teknologi Informasi Dan Ilmu Komputer, 2(5), 2127-2134. 2018

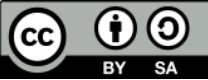

Digital Zone: Jurnal Teknologi Informasi dan Komunikasi is licensed under a Creative Commons Attribution International (CC BY-SA 4.0) 